\title{
Why Paul Was Not Wrong in Quoting Hosea 13:14
}

\author{
ŁUKASZ POPKO \\ École Biblique et Archéologique Française de Jérusalem \\ e-mail: lukasz.popko@dominikanie.pl \\ ORCID: 0000-0003-0546-8692
}

\begin{abstract}
In 1 Cor 15:54-55, Paul quotes Isa 25:8 and Hos 13:14. A significant distance between these citations and the corresponding MT and LXX has been often explained as Paul's intervention. The present article discusses the Hebrew original and compares the citations from 1 Cor 15 with other ancient translations. The polyvalence of the original source, semantic shifts due to the target languages, and accretion of meaning in the transmission process explain Paul's text without a need of charging him of pia fraus. In the end, we try to deduce from this case study some elements of Paul's hermeneutics.
\end{abstract}

Keywords: 1 Cor 15:54-55; Hos 13:14; Isa 25:8; history of reception of the Old Testament; ancient translation techniques.

S ome scholars have argued that the idea of resurrection can be traced to Hoseanic traditions: in particular to Hos 6:1-3 ('after three days he will raise us up") and Hos 13:14. According to this reconstruction, these texts would later influence Isa 24-27 (especially Isa 25:8 and 26:19 would depend on Hos 13:14). Finally, Dan 12:2 remythologised the ancient imagery into the life after death theme ${ }^{1}$. If it is true, Paul in 1Cor 15, where he juxtaposed Isa 25:8 and Hos 13:14 looks like a father of modern exegesis. The problem is that the apparent distance between the MT and Paul's quote is very significant. It is not surprising, therefore, that to the best of my knowledge, the Jewish tradition has not used Hos 13:14 as a proof-text for the resurrection ${ }^{2}$, although otherwise Hosea is used for this purpose quite often. When one reads the context of Hosea 13, this silence of the Jewish tradition is not that surprising because the whole chapter strongly suggests that this oracle is to be taken as an oracle of destruction rather than of salvation.

1 J. Day, "A Case of Inner Scriptural Interpretation. The Dependence of Isaiah XXVI.13 - XXVII.11 on Hosea XIII.4 - XIV.10 (Eng. 9) and Its Relevance to Some Theories of the Redaction of the 'Isaiah Apocalypse'”, JThS 31 (1980) 309-319.

2 T. Bavli Yebamot 1:3-4 II uses the quote of Hos 13:14 in a possibly positive sense, yet it is immediately contrasted with the group of people (from Harpania) who are beyond all remedy; J. Neusner, Hosea in Talmud and Midrash (Studies in Judaism; Lanham, MD - Toronto: Plymouth University Press of America 2007) 141. 
In the present paper, I will evaluate the translation of the prophetic texts provided by Paul and I will reconstruct his hermeneutics and usage of scripture in his sui generis treatise on the resurrection. At the end of this presentation, I will argue that what we can observe in 1Cor is a witness to the eschatological ontology of the word, an expression which I hope will become gradually clearer.

It is both discouraging and encouraging when one discovers almost at the moment of writing conclusions that very similar observations have been already made by someone else. Since in my case, it was Peter J. Tomson, I feel more confident sailing into the less known seas of the Pauline studies as an Old Testament scholar ${ }^{3}$.

\section{1 Corinthians $15: 54-57$}

\subsection{Context}

Paul brings his lengthy discussion on the resurrection to a climax by citing two combined prophecies. In 1 Cor 15:54, Paul argues that the final victory over death comes through Jesus Christ: "when the written word will come to be".

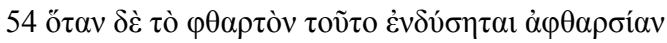

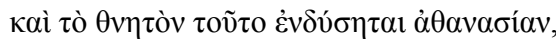

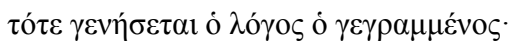

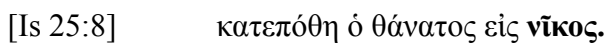

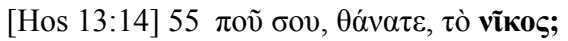

$\pi \mathrm{oṽ} \mathrm{\sigma ov,} \mathrm{\theta \alpha ́v \alpha \tau \varepsilon ,} \mathrm{\tau ò} \mathrm{\kappa \varepsilon ́v \tau \rho ov;}$

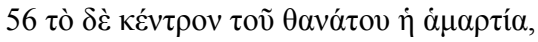

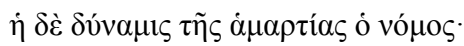

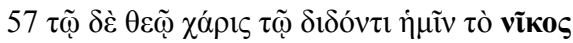

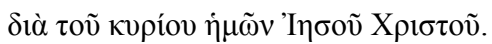

Paul juxtaposes two quotes: the first is from Is 25:8 and the second from Hos 13:14. The whole unit is shaped by the two key words "death" and "victory". In

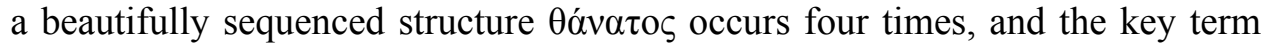

3 For some reason his article on the issue did not find due attention of the commentators: P. J. Tomson, “'Death, where is Thy Victory?' Paul's Theology in the Twinkling of an Eye",, Resurrection in the New Testament. Festschrift J. Lambrecht (ed. R. Bieringer - V. Koperski) (BETL 165; Leuven: Leuven University Press; Peeters 2002) 357-386. 
vĩко $\varsigma$ 'victory' is repeated twice in the quotes, and finally for the third time it is identified with the mission of Jesus Christ.

\subsection{Paul, Where Is Thy "Victory"?}

This structure looks very attractive as it stands. Nevertheless, the commentators point out that both in the Hebrew original and in the LXX of Isaiah and Hosea, these texts read quite differently. The fact that the vocative $\theta$ óv $\alpha \tau \varepsilon$ occurs on the penultimate position instead of the last, is the least impressive difference, since this does not change the meaning of the phrase and can be explained by Paul's rhetorical emphasis. In the Hoseanic citation, the vocative $\theta \dot{\alpha} v \alpha \tau \varepsilon$ corresponds both to Hebrew שֶׁוֶ, but it is and to perfectly possible rendering (as we can see in the analogous case in 2 Sam 22:6). In fact, the most perplexing difference is the seeming absence of the key word "victory" in both Hosea and Isaiah. What is more, whereas the joyful context of the citation from Isaiah agrees with Paul's message, it is difficult to say the same about the dire and threatening Hos 13.

That is why Charles H. Dodd described it merely as "a clear allusion to Hosea conflated with Isaiah" . Charles K. Barrett wrote that Paul "is not here grounding his argument upon Scripture, but writing freely, in scriptural language"5. Richard B. Hays stated that Paul "seems at first glance to pull the scriptural material out of its context" and that Paul thought rather about "that prophetic book's larger message of God's ultimate mercy (see e.g. Hos 11:8-9; 14:4-8)", and that "he [Paul] is following the Septuagint loosely"; and that he "changes he dike (penalty) into to nikos (victory)" to create the otherwise lacking link with Isaiah ${ }^{6}$.

Finally, Steve Moyise in his article "Does Paul Respect the Context of His Quotations?" wrote:

Of course it is possible that Paul knew forms of these texts which did include the word "victory" nikos, but it would be straining credulity to suggest that this was true for both of them. In all likelihood, Paul is responsible for adding the word to at least one of these texts and then identifies the source of this "victory" with "our Lord Jesus Christ. ${ }^{7}$

4 C. H. Dodd, According to the Scriptures: The Sub-Structure of New Testament Theology (London: Nisbet \& Co. 1952) 76.

5 C. K. Barrett, A Commentary on the First Epistle to the Corinthians (BNTC; London: Adam \& Charles Black 1968) 383.

6 R. B. Hays, First Corinthians (Interpretation; Louisville: John Knox 1997) 276.

7 S. Moyise, "Does Paul Respect the Context of His Quotations? Hosea as Test Case", "What Does the Scripture say?" Studies in the Function of Scripture in Early Judaism and Christianity (ed. C. A. Evans - H. D. Zacharias) (LNTS 470; London - New York: T \& T Clark 2012) 40. 
This presumed Pauline biased rendering stirs a theological question whether he respected the inspired Scripture; and indeed some scholars would say that he did not. Moreover, my question is, if these two quotations were made up so freely, how would they work rhetorically? Would they convince his audience? And finally, what was the main point Paul wanted to convince his readers of? I will argue here to the contrary, i.e. that Paul is dealing here in the most literalistic way with his text, without neglecting a single letter.

Last but not least, the logical passage between death, victory, and then in v. 56 the connection between the Law and death, is otherwise less than evident. Since the Law appears as if from nowhere (the phrase $\dot{\eta} \delta \dot{\varepsilon} \delta v ́ v \alpha \mu \iota \varsigma \tau \tilde{\eta} \varsigma \dot{\alpha} \mu \alpha \rho \tau i \alpha \varsigma$ o vó $\mu$ os), some scholars proposed to see here a later addition) ${ }^{8}$. Let us begin a quest for Paul's sources.

\section{Ancient Exegesis of Isa 25:8}

\begin{tabular}{|c|c|c|}
\hline \multicolumn{3}{|c|}{ Isa $25: 8$} \\
\hline Quote in 1Cor & MT & LXX \\
\hline 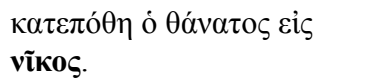 & 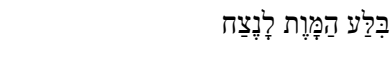 & 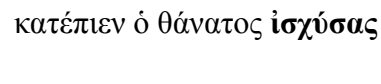 \\
\hline $\begin{array}{l}\text { Death was swallowed up in } \\
\text { victory }\end{array}$ & $\begin{array}{l}\text { He has swallowed death } \\
\text { forever }\end{array}$ & $\begin{array}{l}\text { Death swallowed [them?], } \\
\text { having prevailed }\end{array}$ \\
\hline
\end{tabular}

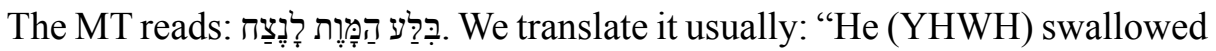
death forever", even though, since there is no nota accusativi, "death" can be the subject of the verb. The third word is i.e. which is usually translated as the noun בֵֵַ "perpetuity"; thus: "forever".

The LXX reads something quite opposite to most of our modern translations, for death is taken as the subject of the phrase: "Death swallowed (them?), having prevailed". The context allows us to understand this phrase not as a final demise of death but rather that death functions as a divine instrument against the nations ${ }^{9}$.

The aorist participle i $\boldsymbol{\sigma} \boldsymbol{\chi} \boldsymbol{\chi} \boldsymbol{v} \boldsymbol{\sigma} \boldsymbol{\alpha} \boldsymbol{\varsigma}$ may seem surprising but it can be understood as a possible interpretation of the noun נֵֵֵָ ${ }^{10}$. Indeed, among the ancient inter-

8 See the discussion in: Tomson, "'Death, where is Thy Victory?", 360.

9 W. de Angelo Cunha, "Greek Isaiah 25,6-8 and the Issue of Coherence", XIV Congress of the IOSCS, Helsinki, 2010 (ed. M. K. H. Peters) (Atlanta, GA: SBL 2013) 288-290.

10 According to R. Morissette ("Un midrash sur la mort (I Cor., XV, 54c à 57)", $R B 79$ [1972] 169), this rendering is "defectif". In other cases, the LXX of Is renders נצח also in a temporal way: in 13:20 it

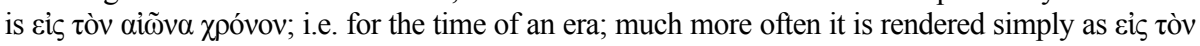

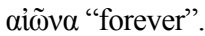


pretations of this line, a variety of options becomes evident. Interestingly, none

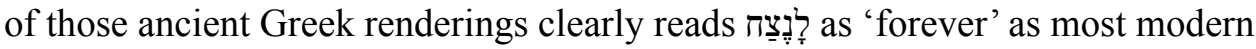
commentators do.

\begin{tabular}{|c|c|c|c|c|c|}
\hline \multicolumn{6}{|c|}{ Isa $25: 8$} \\
\hline MT & LXX & 1Cor & Aquila & Symmachos & Theodotion \\
\hline 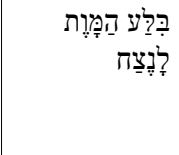 & 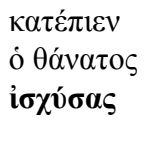 & 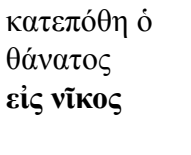 & 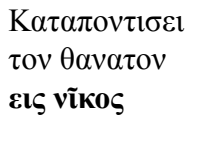 & 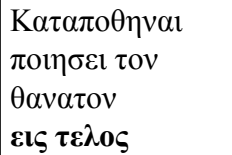 & 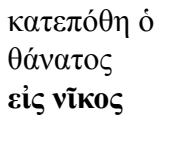 \\
\hline $\begin{array}{l}\text { He has } \\
\text { swallowed } \\
\text { death } \\
\text { forever }\end{array}$ & $\begin{array}{l}\text { Death } \\
\text { swallowed } \\
\text { (them?), } \\
\text { having } \\
\text { prevailed }\end{array}$ & $\begin{array}{l}\text { Death was } \\
\text { swallowed up } \\
\text { in victory }\end{array}$ & $\begin{array}{l}\text { He will plunge } \\
\text { the death } \\
\text { in victory } \\
\text { [/forever?] }\end{array}$ & $\begin{array}{l}\text { It will make } \\
\text { death to be } \\
\text { swallowed down } \\
\text { completely }^{11}\end{array}$ & $\begin{array}{l}\text { Death was } \\
\text { swallowed up } \\
\text { in victory [/ } \\
\text { forever?] }\end{array}$ \\
\hline
\end{tabular}

Our understanding of these phrases is complex because of the developments of the Hebrew language (with reference to the Hebrew נֵֵֵ) and, on the side, with reference to Jewish Greek idiom, our interpretation of घi $\varsigma$ vĩkos. For example, whereas Koehler, Baumgartner and Stamm's The Hebrew and Aramaic Lexicon of the Old Testament (HAL/HALOT) presents two entries for ניצֵ, in the recent Dictionary of Classical Hebrew David J.A. Clines has four of them: נֵַָּח

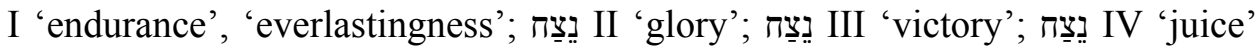

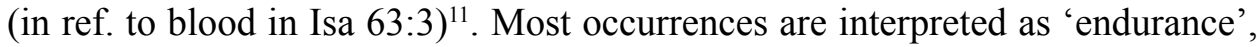
or 'forever'; i.e. נַצִ I. The II meaning; i.e. 'glory', can be reduced just to a few cases and explained by the growing influence of Aramaic like in $1 \mathrm{Chr}$ 29:11 or

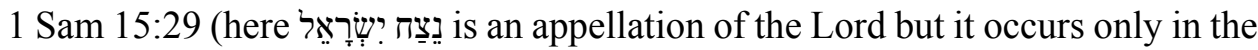
secondary expansion of the $\mathrm{MT}^{12}$ ).

The third נגבצח, meaning 'victory', which interests us most, was identified by Clines in the War Scroll from Qumran (1QM 4:13). There we read that when the people withdraw from a battle they were to write on their signs a series of divine attributes beginning with ישועות אל "Deliverances of God" and "Victory of God". Victory becomes a common meaning of נַצב in Syriac and Aramaic as well as in post-biblical Hebrew ${ }^{13}$.

11 L. Koehler - W. Baumgartner - J. J. Stamm (eds.), The Hebrew and Aramaic Lexicon of the Old Testament (Leiden: Brill 1994-1999) III, 716; D. J. A. Clines (ed.), The Dictionary of Classical Hebrew (Sheffield, England: Sheffield Academic Press 1993-2011) V, 914.

12 There are good arguments doubt the originality of the MT and to prefer the LXX; see G. Auld, I\& II Samuel: A Commentary (OTL; Louisville, KY: Westminster John Knox 2011) 178.

13 W. Harrelson, "Death and Victory in 1 Corinthians 15:51-57: The Transformation of a Prophetic Theme", Faith and History. Essays in Honor of Paul W. Meyer (ed. J. T. Carroll et al.) (Atlanta, GA: 
This Aramaic influence on Middle Hebrew explains why around I c. AD even

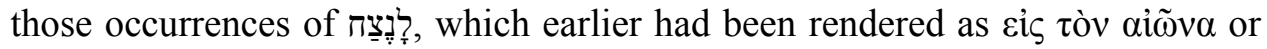

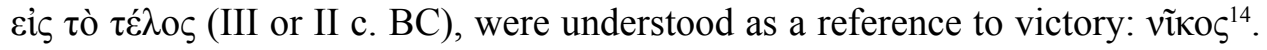

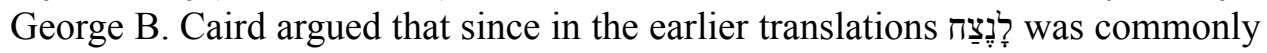
known as 'forever', the later Greek translators must have made the change de-

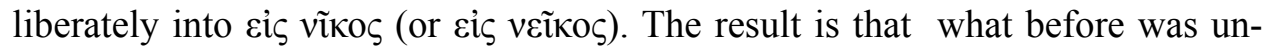
derstood as a rather indefinite temporal reference, came now to be understood as "until victory is won", which is, in fact, quite a curious phrase ${ }^{15}$. Robert A. Kraft

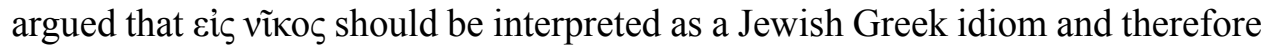

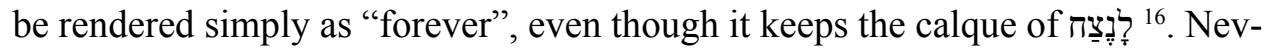
ertheless, the case of 1 Cor 15 actually proves the contrary because Paul takes vĩo $\zeta$ in its regular meaning of "victory' ${ }^{17}$.

Indeed, this Hebrew-Aramaic-Greek expression must have been of a particular interest for the attentive readers because it suggested some eschatological meaning. We can conclude therefore, that in 1 Cor Paul uses a correct translation

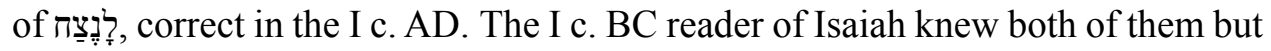
I do not think that he felt compelled to choose between the meaning 'forever' and 'until the victory'. Rather, those connotations functioned at the same time and Paul used this semantic potential in 1 Cor 15 because here both the eschatological time ('it shall come to pass', v. 54) and a victory are essential.

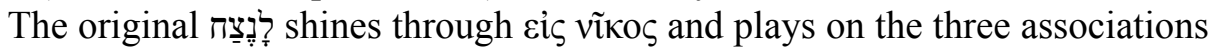
: 1) "forever", 2) "to victory", 3) "to completeness". Victory, completeness, and finality - these three qualities explain why this phrase became so important in the post-LXX translations. Since this נִֵֵֵ i.e. 'end' now also means "victory", it fits perfectly these eschatological scenarios which announce some kind of an eschatological war.

Scholars 1990) 154. The corresponding verb can also be found only in the Qumranic Hebrew (1QM 16:9; 17:15; Temple Scroll ${ }^{A}=11 \mathrm{QT}$ 58:11; 4QBark $\left.{ }^{\mathrm{c}} 1,1\right)$.

14 This has been noted already by Driver. The phrase לנצח is rendered as عiֹ vĩאo 1:11, 8:7; Jer 3:5; Lam 5:20. A similar expression which usually occurs in the Psalms' titles. The simi-

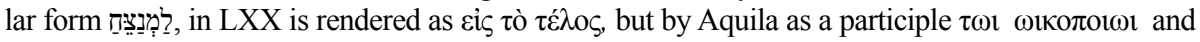

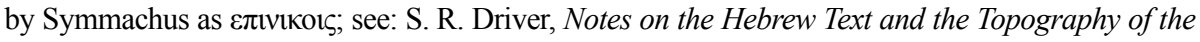
Books of Samuel: With an Introduction on Hebrew Palaeography and the Ancient Versions (London: Oxford University Press, Clarendon Press $\left.{ }^{2} 1913\right) 129$.

15 G. B. Caird, "Towards a Lexicon of the Septuagint. II", JThS 20 (1969) 24.

16 R. A. Kraft, "Eis neikos = permanently/successfully: 1 Cor 15:54, Matt 12:20", Septuagintal Lexicography (ed. R. A. Kraft) (SCSt.SBL 1; [printed in Missuola, MT]: SBL 1972) 154. See the same polyvalence observed in T. Muraoka, A Greek-English Lexicon of the Septuagint (Louvain - Paris - Dudley, MA: Peeters 2009) 474-475.

17 In 1906, R. R. Ottley (The Book of Isaiah According to the Septuagint (Codex Alexandrinus), I, Text and Notes [Cambridge: Cambridge University Press 1906] 226-227) anachronistically wrote that St. Paul quotes the verse 'in the words of Theodotion's version'. I leave to others the discussion on this peculiar agreement between Paul and this Jewish Hellenistic author who lived at least one hundred years after Paul. 


\section{Hos 13:14}

Paul was not the first to believe in the resurrection; also his choice of Isa 25:8 to speak about the victory against death seems quite unproblematic. It is much more troublesome, and indeed this is also one of the questions of the present paper, why Paul chose Hos 13:14? Did he intend to make of it a proof text of resurrection? The context of Hosea MT is clearly negative and at the first hand it does not look like a good candidate.

\subsection{Pythian Obscurity of the Hebrew Original}

The preceding phrase in the same verse is formulated in two imperfects:

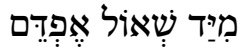

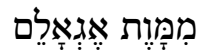

These verbal forms bring with them the usual ambiguity of the imperfect.

1. Because of this apparently negative outcome of v. 15 , the modern translations often interpret the first two phrases as rhetorical questions: "Shall I ransom them?" and "Shall I redeem them?" (e.g. BJ, NRSV, Macintosh ${ }^{18}$ ).

2. Rashi and Ibn Ezra interpreted them as frequentative in the past. Rashi: "I used to redeem them in the past but now I will speak the words of death against you". Ibn Ezra: "I liberated your fathers, but now, I will become your pestilence of death". Kimchi follows a very similar opposition between past and present or future "I liberated them from the hand of Sheol, when they were wise, but now when he is not wise, but stupid and denied my good things [...], I will become a death upon you, by bringing sword, hunger, and wild animals" 19 .

3. The LXX took the most simple and common option by rendering the two verbs as future indicatives. This also opens the text for a positive interpretation $^{20}$. Jerome also understood it as a simple promise of the future salvation.

18 A. A. Macintosh, A Critical and Exegetical Commentary on Hosea (ICC; Edinburgh: T \& T Clark 1997) 546.

19 Quoted after: A. Wünsche, Der Prophet Hosea: Übersetzt und erklärt mit Benutzung der Targumim, der jüdischen Ausleger Raschi, Aben Ezra und David Kimchi (Leipzig: Weigel 1868) 570.

20 The editors of Bible d'Alexandrie even that it "donne une prophetie du salut"; E. Bons, J. Joosten, S. Kessler, Les Douze Prophètes, Osée (La Bible d'Alexandrie 23/1; Paris: Éditions du Cerf 2002) 161; see also A. Gelston, The Twelve Minor Prophets (BHQ 13; Stuttgart: Deutsche Bibelgesellschaft 2010) $72 *$. 
4. The imperfects can express a possibility: "I could ransom them" and "I could redeem them".

Some authors see in 1 Cor 15 a proceeding similar to gezera Shawa of Hillel ${ }^{21}$.

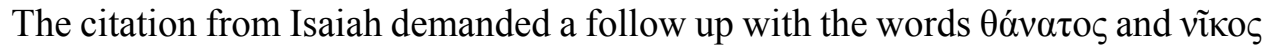
and Hos 13:14 is the only such a verse in the Scriptures. Furthermore, its ambiguity works perfectly to demonstrate both the truthfulness of the Word of God and its quality of a "two-edged sword": killing and saving. We have seen that citing Isaiah, Paul did not follow the LXX. In the case of Hosea 13:14, he seems to have chosen consciously the translation which is closest to the LXX.

\begin{tabular}{|c|c|c|}
\hline \multicolumn{3}{|c|}{ Hos $13: 14 b$} \\
\hline Quote in 1Cor & MT & LXX \\
\hline 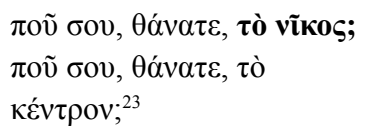 & 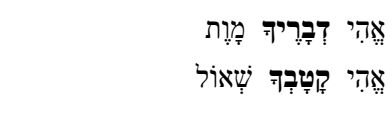 & 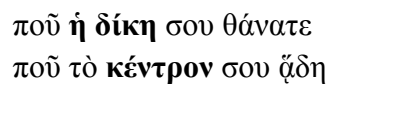 \\
\hline $\begin{array}{l}\text { Where is yours, O Death, } \\
\text { victory?! } \\
\text { Where is yours, O Death, } \\
\text { sting?! }\end{array}$ & $\begin{array}{l}\text { Where are your pestilences, } \\
\text { O Death? } \\
\text { Where is your destruction, } \\
\text { O Sheol? }\end{array}$ & $\begin{array}{l}\text { Where is your penalty/justice, } \\
\text { O Death! } \\
\text { Where is your sting, } \\
\text { Hades! }\end{array}$ \\
\hline
\end{tabular}

I will not say much here about the difficulty of the word wֶ which occurs only in this chapter of the Hebrew Bible (also in Hos 13:10). For more than two thousand years the two major possibilities have persisted: 1) אֶֶ, is a verb: the 1st pers. sg. imperfect apocopated form of הָָיז "to be" (so Aquila, Symmachus, V); or 2) it is a form of interrogative particle "where?" (so LXX, 1 Cor and S). Actually, both interpretations can be understood as a judgement or a salvation oracle, depending on whether the genitive case is taken as objective (death being destroyed) or subjective (death destroying).

The sentence "Where is your destruction, O Death?" can be read as God mocking death or God calling upon death. Similarly, when we read אֶ as "I will be..." the ambiguity persists:

"I will be your destruction of death (i.e. deadly destruction)." The people is addressed (Rashi, Ibn Esra, Kimchi) ${ }^{22}$ and the phrase announces a future destruction of the people.

or:

"I will be your destruction, O death!" Here, death is addressed (Jerome) and the phrase is announcing a future destruction of death.

22 Wünsche, Der Prophet Hosea, 573 


\subsection{Hos 13:14 according to the LXX: God-Sent Pestilence or God's Word ?}

This is not the end of the fruitful ambiguities. As we have noted, Paul in the case

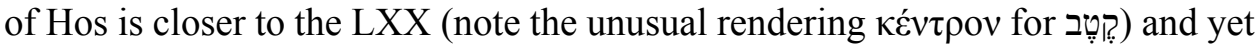
we still cannot find the "victory" either in the MT, or in LXX.

\begin{tabular}{|c|c|}
\hline LXX to Hos & Quote in 1 Cor 15 \\
\hline 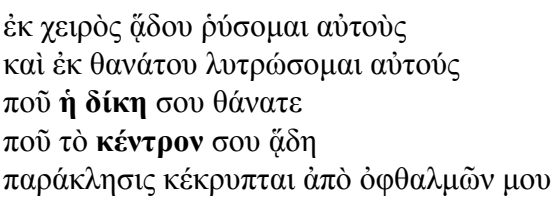 & 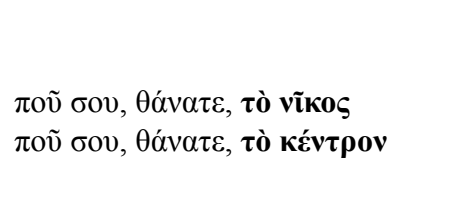 \\
\hline $\begin{array}{l}\text { Where is your penalty/justice, Death? } \\
\text { Where is your sting, Hades? }\end{array}$ & $\begin{array}{l}\text { Where is yours, O Death, victory?! } \\
\text { Where is yours, O Death, sting?! }\end{array}$ \\
\hline
\end{tabular}

The word דִבְרָריף is nowadays commonly understood as "your plagues" and its basic form is recognised as Tְּ? "pestilence". More precisely, one can correctly argue that דֶֶֶ in some texts appears as a destructive messenger of YHWH (see especially 2 Sam 24:15-16) together with other "messengers of evil" known also

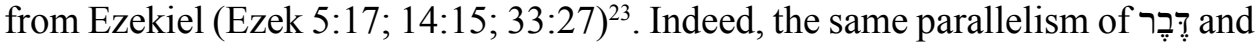
קֶֶ, occurs both in Hos 13:14 and Ps 91:6.

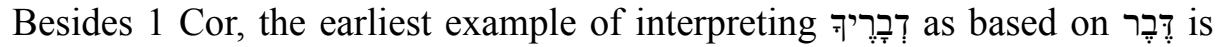
witnessed to by the Jewish translation by Symmachus:

\begin{tabular}{l|l}
$\varepsilon \sigma 0 \mu \alpha 1 \pi \lambda \eta \gamma \eta \boldsymbol{\sigma o v} \varepsilon v \theta \alpha \nu \alpha \tau \omega \mathrm{l}$ & I will be your plague in death \\
$\varepsilon \sigma o \mu \alpha 1 \alpha \kappa \eta \delta 1 \alpha(\alpha \pi \alpha \nu \tau \eta \varepsilon \mu \alpha) \sigma o v \varepsilon v \alpha \delta \eta$ & I will be your torpor (meeting?) in Hades
\end{tabular}

The situation gets more complicated when one realises that in the LXX, the

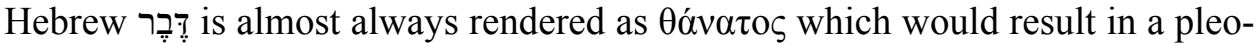
nastic translation "I will be your death, o Death". This is, by the way, exactly the translation chosen by Jerome (Ero mors tua, O mors!).

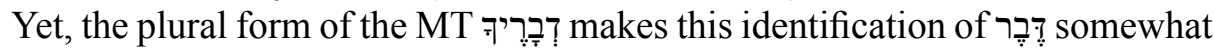
unusual. In fact, it would be the only occurrence where ?ִ ?ִ would have a plural form. What is more interesting for the study of the history of reception is that none of the remaining ancient versions followed this path.

23 See a review of positions on this matter in: J. M. Blair, De-demonising the Old Testament. An Investigation of Azazel, Lilith, Deber, Qeteb and Reshef in the Hebrew Bible (FAT II/37; Tübingen: Mohr Siebeck 2009) 30-32, 175-176. 


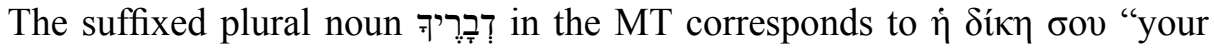
judgement", or "your punishment" in the LXX. Also Theodotion's translation contains the same word "judgement", although the phrase addresses the people rather than Death:

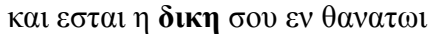
$\kappa \alpha 1 \eta \pi \lambda \eta \gamma \eta$ бov $\varepsilon v \alpha \delta \eta$
And your judgement will be through death

And your plague in Hades.

How did the LXX and Theodotion arrive at this? Firstly, a different Vorlage

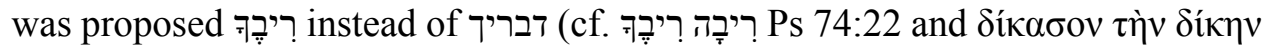
бov; cf. also Am 7:4 and Mi 7:9) ${ }^{24}$. Nevertheless, the second and more probable

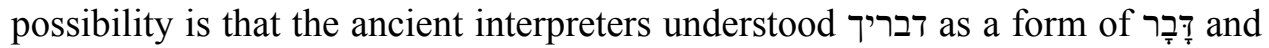

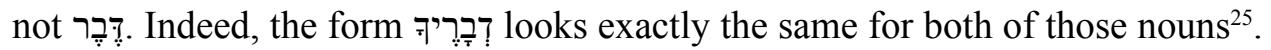
There is exactly nothing in the morphological form which would allow the reader to distinguish them.

Among the various meanings of the Hebrew "case for judicial investigation", a "plea" (Ex 18:16.22; 22:8 etc.). In that case,

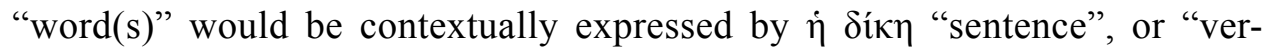
dict", i.e. the words pronounced at the conclusion of the legal strife before the judge ${ }^{26}$. This seems indeed to explain $\dot{\eta} \delta$ ík $\eta$ in the LXX and Theodotion's translation ${ }^{27}$.

\subsection{A Fruitful Convergence: דֶֶּר}

Other ancient Jewish translations (as well as more recently Rashi, Kimchi and Ibn Esra) also read in Hos 13:14b the word דָָּ It It occurs so much more often than the ancient translators would follow this interpretation.

Thus in Aquila's translation we read:

24 This was proposed already by Michaelis; see J. F. Schleusner, Novus Thesaurus philologico-criticus sive lexicon in LXX et reliquos interpretes graecos ac scriptores apocryphos Veteris Testamenti (Lipsiae: Verlag Weidmann 1820) II, 169.

25 Eg. Ps 90:3.6 in the LXX witnesses to the interpretation of the consonantal text as

26 Muraoka, A Greek-English Lexicon of the Septuagint, ad loc.

27 Thus also: Schleusner, Novus Thesaurus, II, 169. 
Aquila's $\varepsilon \sigma o \mu \alpha \imath \rho \eta \mu \alpha \tau \alpha \sigma o v, \theta \alpha v \alpha \tau \varepsilon$ results in a strange phrase 'I will be your words, o Death!'. It sounds as if the speaking subject (the prophet or God himself) declared that his words will become the words of death, i.e. death-bringing words.

The same interpretation רฺָָָָ, but closer to the plural form of the MT, is found

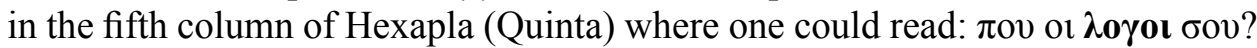
'Where are your words?'

We need to note that reading בָָ Tָ preserves the ambiguity of the message: God is fighting against death or fighting with Death at his side. The case of Isa 9:7 is very illuminating here. In the MT, we read: "the Lord has sent a word

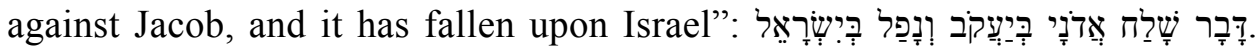

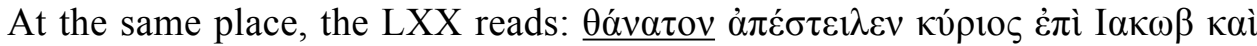
$\tilde{\eta} \lambda \theta \varepsilon v \varepsilon \dot{\varepsilon} \pi$ I I $\rho \alpha \eta \lambda$ ! It is easy to decipher the vocalisation demonstrates that actually there are some texts in which both meanings are perfectly possible.

The destructive divine words can be found of course in the context of the Exodus narrative and in particular in the famous midrashic text in the book of the Wisdom of Solomon. Here the Word coming from heaven falls upon "the doomed land" of Egypt bringing death. The heavenly Logos is bringing the divine decree with him as a sharp sword:

\begin{tabular}{|c|c|}
\hline \multicolumn{2}{|c|}{ Wis $18: 15-16 a$} \\
\hline 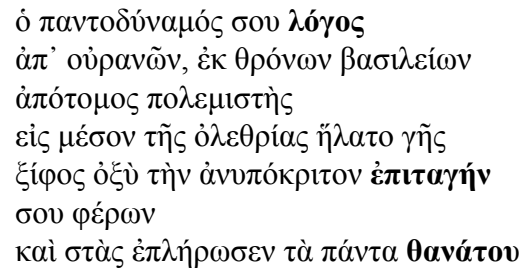 & $\begin{array}{l}\text { Thy Almighty word } \\
\text { leaped down from heaven out of thy royal throne, } \\
\text { as a fierce man of war } \\
\text { into the midst of a land of destruction } \\
\text { bringing you unfeigned commandment as a sharp } \\
\text { sword, } \\
\text { and standing up filled all things with death }\end{array}$ \\
\hline
\end{tabular}

Indeed, the very word דִבְָרָר maintains an intrinsic potentiality and in Hosea 13:14 "the word of death", "the case of death" and "the pestilence of death" remain indistinguishable. The reception history demonstrates how "ָ̣? a divine messenger of pestilence, becomes exchangeable and easily identified with God-

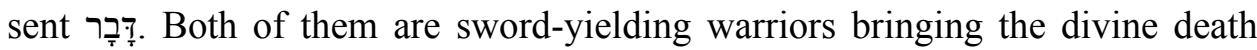
sentence upon the wicked. 
Such a conflated or maybe better to say multi-layered exegesis is proposed by the Targum Jonathan ${ }^{28}$. In the past the punishment was brought by an angel, now it will be the divine Word, and what is more, his written decree!

I have delivered the house of Israel from the killer

and rescued them ${ }^{29}$ from the destroyer (destroying angel).

But now my word (מימרי) shall be against them to kill, and my decree (פתגמי) will be to destroy.

Because they have transgressed my law,

I shall remove my Shekinah from them ${ }^{30}$.

In his exegesis of Hosea, the targumist is interpreting the personified Death

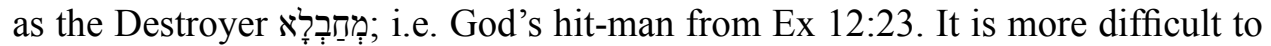

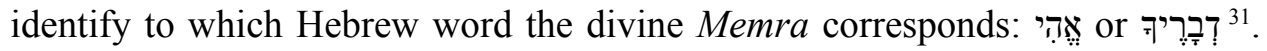
The seemingly more mythological Hebrew דָּ? "pest" and "pestilence" is thus identified with another apparently not less destructive Aramaic pair memra and pitgama. This last word often refers to a written document.

Death and the Word both come from God and there is no opposition between them, since they are both his agents. Are we far from the ambivalent position of the Law in Paul's perspective: life-giving and potentially mortiferous?

\subsection{Paul, Whence Is Thy "Victory"?}

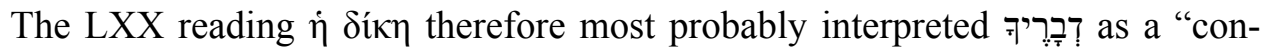
demning word", a "sentence". But this still does not explain how Paul got "victory" into his citation of Hosea. A look at the versions allows us to note that the same meaning is present in the old Syriac version (The Peshitta):

28 Targums are notoriously difficult to date. $\mathrm{Tg}$. Prophets had an oral prehistory but it was put to writing after $70 \mathrm{AD}$. One finds its influences already in the Peshitta. See the discussion in: K. J. Cathcart - R. P. Gordon, The Targum of the Minor Prophets (ArBib 14; Collegeville, MN: Liturgical Press 1989) 16-18. For our main argument, it is enough to state that Paul's interpretation of Hosea agrees with what was in the air during his lifetime. We do not claim here any direct dependence of 1 Cor to a specific ancient Jewish translation.

29 The targumist rendered the first two yiqtol verbs as iteratives in the past tense and created thus an opposition with the future announcement of punishment.

30 Cathcart - Gordon, The Targum of the Minor Prophets, 59-60.

31 Tomson ("'Death, where is Thy Victory?"', 377) considers it as a circumlocution for the divine subject and identifies it with the אֶּ interpreted as "I will be". 


\begin{tabular}{|l|l|}
\hline \multicolumn{1}{|c|}{ Peshitta to Hos } & \multicolumn{1}{|c|}{1 Cor } \\
\hline $\begin{array}{l}\text { Where is now your victory } \text { ₹ hrov, Death? } \\
\text { Or where is your sting Shyol? }\end{array}$ & $\begin{array}{l}\text { Where is your, Death, victory?! } \\
\text { Where is your, Death, sting?! }\end{array}$ \\
\hline
\end{tabular}

Out of all the ancient versions, at this point it is Paul's text which is surpris-

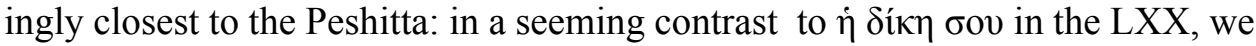
read here the "victory" of death.

Scholars have excluded the possibility that here the Peshitta of Hosea would depend on the Peshitta of 1 Cor 15. This Syriac translation bears some influence of the LXX in some places, including Hos 13:14, which is why its translator could hardly belong to rabbinic Judaism. Nevertheless, the Peshitta of the Twelve prophets bears no traces of Christian interpretation; on the contrary, some additions equate the people of God with Israel (Zeph 2:10.15). In this particular case of Hos 13:14, the direct influence of the NT Peshitta is to be excluded ${ }^{32}$. In the Peshitta to Hos 13:14, we are dealing therefore with an independent ancient Jewish translation, even though inspired by the $\mathrm{LXX}^{33}$.

The Peshitta to Hos translated דבריך by the Syriac noun $z \bar{a} k \underline{k}$, whose first meaning is "victory". This particular Syriac rendering can be explained as anoth-

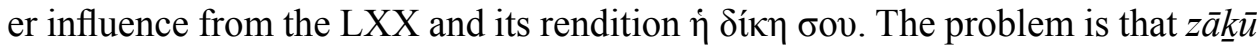

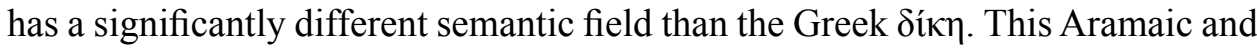
Syriac word, as well as its cognates, does not concern only the field of justice: it is "innocence" and "justification" but also "victory" 34 .

At the end of his short recension of Gelston's book, Michael Weitzman suggested an analogous origin of Paul's tò vĩкos in $1 \mathrm{Cor}^{35}$. Indeed, it looks as if Paul also was thinking in Aramaic, in which "justice" and "victory" are expressed by the same term. The use of "victory" does indeed fit his ideas but it is not a free or abusive manipulation on his part. We cannot exclude that it was not Paul's invention but a possible rendition of the words of the Hebrew prophet, influenced by some pre-existing Greek translation and Aramaic semantics.

32 A. Gelston (The Peshitta of the Twelve Prophets [London: Oxford University Press: Clarendon Press 1987] 154) notes that the two nouns 'sting' and 'victory' in the Peshitta of 1Cor 15:56 are inverted.

33 According to J. Joosten (Language and Textual History of the Syriac Bible [TS III/9; Piscataway, NY: Gorgias 2013] 12-16), this translatory project started ca. 150 AD with the Pentateuch and followed the canonical order (historical books, prophets, and the writings), ending ca. $200 \mathrm{AD}$. Only the last books, like Proverbs, demonstrate some traces of the ideas very close to Christian thought.

34 See R. Payne Smith et al., Thesaurus Syriacus (London: Oxford University Press, Clarendon Press 1879) I, 1119-1121. The Syriac adjective zakkāy means "just" but also "victorious"; for the verb $z k y$ in D we will find the meanings: "to justify", "to make victor", and "to correct".

35 M. Weitzman, "Recension of The Peshitta of the Twelve Prophets. By A. Gelston", JThS 40 (1989) $162-165$. 


\section{Conclusions: Paul's Approach to the Scriptures}

To conclude, we will propose a set of observations which can be derived from our investigation of Paul's dealings with the prophetic texts.

\subsection{Paul Provides a Correct Literal Translation}

Paul does not use 'allusion' or a vague 'scriptural language'. In his citation not a single word is omitted or rendered by a double translation. Hos 13:14 has remained a difficult and ambiguous text for the modern translators; Paul did his work as translator well, respecting every single word and using the knowledge of his time. His choices are within the bounds of grammatical and semantic possibilities. Paul knew the Hebrew text, its subtleties and most probably also a number of interpretations ${ }^{36}$.

\subsection{In Texts Submitted to Intensive Interpretation along the Process of Transmission, the Target Language Does Not Cancel the Semantic Field of the Source Language}

We have observed how the ambiguous דבריך gave rise to an exegesis that su-

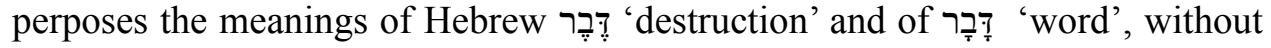
eliminating any of them. Turning it into a contextual rendering like the Greek

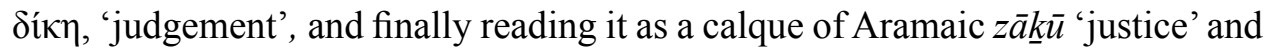
'victory' did not annul the connotations of the Hebrew original. On the contrary, Paul's conclusion in v. 56 makes sense if the reader keeps all these connotations in mind. Even if in the target language an expression (like vĩкo $\varsigma$ 'for victory', 'forever', 'glory') becomes a new idiom, the original Hebrew still "shines through" it via Aramaic and Greek.

Paul does not force his readers to choose between the possible connotations of the traditional text. On the contrary, although in a less explicit way than the Targum of Jonathan did, Paul invites his readers to keep in mind the possible meanings of the written word, and later, in consequence, of the Law.

36 Tomson ('“'Death, where is Thy Victory?', 377, n. 65) declares Paul's familiarity with a number of accepted Greek versions, yet, our knowledge is too limited to move beyond a suggestion. 


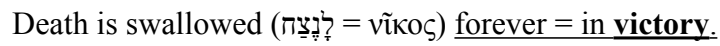

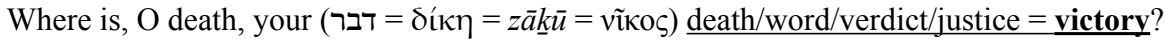

Where is, O Death, your sting?

For the sting of Death is sin and the power of $\sin$ is the Law

but thanks be to God, who gives us (vĩкo $\varsigma=z \bar{a} k \underline{u} \bar{u}$ ?) the victory $=$ justification $/$ merit

through our Lord Jesus Christ.

This procedure, which is proper to any living tradition, results in an accumulation of connotations. It is difficult to know to what degree it was a methodical and consciously performed process.

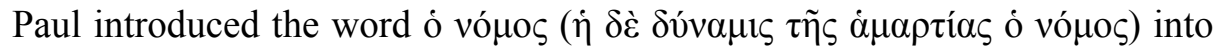
his conclusive statement and connected it with death, even though this is not "at stake" in this letter. Indeed, studying the history of reception shows that the word Tִבְרָיך has been variously interpreted as 'word', 'death', 'written document', 'judgement', 'justification', or 'victory'! To grasp Paul's comparison in which different vĩאo $\varsigma$, i.e. of different origins, are juxtaposed one needs to keep in mind the superimposed meanings.

Actually, the case of דבריך from Hos 13:14, where the word "דבר" is open to different interpretations is a perfect mise en abyme of the hermeneutic process: the reader beginning from the same divine word may arrive at "death" or/and at "victory".

\subsection{Paul's Exegesis Has Christological Aims}

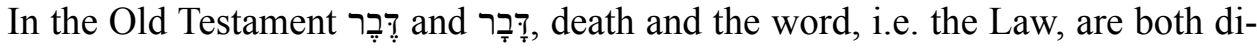
vine agents, as Jesus Christ is in the New Testament. They bring their respective vĩко:: retribution/justice/victory. Yet, in the future victory described by Paul the vĩко $\varsigma$ will be different, for it will be given by God through Jesus Christ: it will bring not a destruction but imperishability.

Using the same term, vĩкo , Paul intends to demonstrate the contrast between the agents of the divine judgement (death and the divine word) and Jesus Christ. They all may bring vĩко 'commandment', whereas the vĩкo given by Christ is 'victory', 'justification', and 'glory'. 


\subsection{Paul Is More interested in the Word of God (in the Singular!) Than in the Words (Plural) of the Prophets}

The very formula by which Paul introduces the two quotes is very telling: $\tau$ ó $\tau \varepsilon$

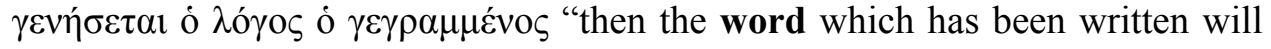
come to be". Paul is not interested in the presumed intention(s) of the prophetic author, nor in any reconstructed or deduced ipsissima verba of Hosea or Isaiah. That is why Paul does not mention them at all. This may also explain why Paul does not seem to care about the negative context of Hos $13^{37}$.

That is also why he speaks about the "written word" in the singular. Once written, engaged in the transmission process, eventually canonised, the human words are detached from their original enunciative framing, suspended as it were beyond regular space and time - hence trans-historic and always valid, beyond any intentions of any human author. Paul's insistence on the "word which was written" emphasises the apocalyptic ontology of the text itself, i.e. its independence from its original human speaker or writer, from the historical context of its origins, as well as its capacity to address future readers.

A similar formula in which the written word is looks like the means of divine action occurs already in Jer 25:13 ${ }^{\mathrm{MT}}$ :

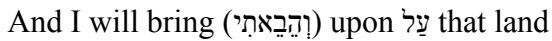

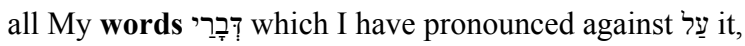

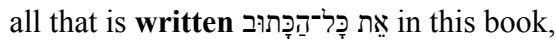
which Jeremiah has prophesied against all the nations.

The words of God brought upon or against the land are here the divine agents, more efficacious than the warriors being led to battle; cf. Jer 25:9. What had been written in the Oracles Against the Nations will come to be, or more precisely be "brought against". A similar expression explains what happens when the written covenant is broken in Dt 29:26. Also in this case, YHWH 'brings against the people the curse as it was written':

Therefore, the anger of the LORD burned against that land,

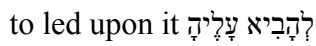

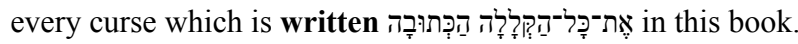

37 Ancient readers were very aware of the glaring contrast between the oracles of doom and of salvation juxtaposed in Hosea. In Sifre to Numbers CXXXI:I we read: "R. Aqiba says: 'Every passage contiguous to another provides an appropriate occasion for a lesson to be derived therefrom'. Rabbi says, 'There are many passages near one another or distant from one another as east from west'; Neusner, Hosea in Talmud and Midrash, 6-7. See also Sifre to Deut CCCXLII:I; ibidem,15; Pesiqta de Rab Kahana XVI:VIII; ibidem, 76-77. 
Scholars have already noted the parallels of the formula applied by Paul in 1 Cor 15:54 introducing the biblical citations with the formula found in the Damascene Document. There we read about the coming punishment: "upon them the word (or thing) will come as it was written in the words of the prophet

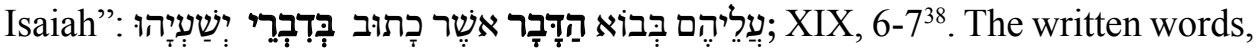
in the plural, of Isaiah (DD VII, 9-10), precede the coming of the Word, in the singular; i.e. the thing, the event ${ }^{39}$.

Paul likewise does not intend, therefore, to introduce only the prophetic words (in the plural) of Isaiah or of Hosea. He is referring to both the Word of God written in their words and its performative effect, the event, the thing, which is written in their words.

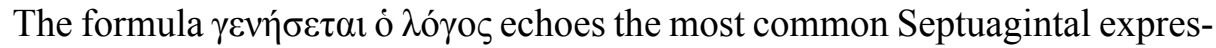

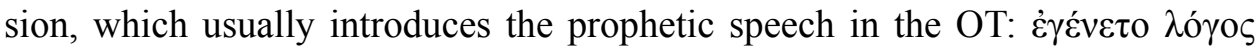
кupíov. This common Greek phrase renders the difficult Hebrew expression

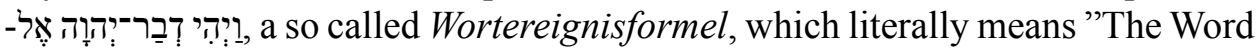
of YHWH has become/came to be to N". The "thing / word that happened to" Hosea (Hos 1:1), Isaiah (Isa 2:1), and other prophets "will be" at the resurrection of the dead announced in 1 Cor. Paul, although quoting the diverse words of the known prophecies, intends to emphasize that he is announcing in 1 Cor the same single written Word. It is not just the ultimate meaning of scripture to be revealed at the end of time, it is the same one and only divine agent.

\section{Bibliography}

Auld, G., I \& II Samuel: A Commentary (OTL; Louisville, KY: Westminster John Knox 2011). de Angelo Cunha, W., "Greek Isaiah 25,6-8 and the Issue of Coherence", XIV Congress of the IOSCS, Helsinki, 2010 (ed. M. K. H. Peters) (Atlanta, GA: SBL 2013) 277-290.

Barrett, C. K., A Commentary on the First Epistle to the Corinthians (BNTC; London: Adam \& Charles Black 1968).

Blair, J. M., De-demonising the Old Testament. An Investigation of Azazel, Lilith, Deber, Qeteb and Reshef in the Hebrew Bible (FAT II/37; Tübingen: Mohr Siebeck 2009).

Bons, E. - Joosten, J. - Kessler, S., Les Douze Prophètes, Osée (La Bible d'Alexandrie 23/1; Paris:

Éditions du Cerf 2002).

Caird, G. B., "Towards a Lexicon of the Septuagint. II", Journal of Theological Studies 20 (1969) 21-40.

Cathcart, K. J. - Gordon, R. P., The Targum of the Minor Prophets (ArBib 14; Collegeville, MN: The Liturgical Press 1989).

38 Morissette, "Un midrash sur la mort", 166.

39 See at the same place formula introducing the citation from Zechariah. It is likewise the announcement of the "coming of the word upon" enemies with the same change between plural and singular of דָָּ 
Clines, D. J. A. (ed.), The Dictionary of Classical Hebrew (Sheffield, England: Sheffield Academic Press 1993-2011) V.

Day, J., "A Case of Inner Scriptural Interpretation. The Dependence of Isaiah XXVI.13 - XXVII.11 on Hosea XIII.4 - XIV.10 (Eng. 9) and Its Relevance to Some Theories of the Redaction of the 'Isaiah Apocalypse“", Journal of Theological Studies 31 (1980) 309-319.

Dodd, C. H., According to the Scriptures: The Sub-Structure of New Testament Theology (London: Nisbet \& Co. 1952).

Driver, S. R., Notes on the Hebrew Text and the Topography of the Books of Samuel: With an Introduction on Hebrew Palaeography and the Ancient Versions (London: Oxford University Press, Clarendon Press ${ }^{2}$ 1913).

Gelston, A., The Peshitta of the Twelve Prophets (London: Oxford University Press: Clarendon Press 1987).

Gelston, A., The Twelve Minor Prophets (BHQ 13; Stuttgart: Deutsche Bibelgesellschaft 2010).

Harrelson, W., "Death and Victory in 1 Corinthians 15:51-57: The Transformation of a Prophetic Theme", Faith and History. Essays in Honor of Paul W. Meyer (ed. J. T. Carroll et al.) (Atlanta, GA: Scholars 1990) 149-159.

Hays, R. B., First Corinthians (Interpretation; Louisville: John Knox 1997).

Joosten, J., Language and Textual History of the Syriac Bible (TS III/9; Piscataway, NY: Gorgias Press 2013).

Koehler, L. - Baumgartner, W. - Stamm, J. J., The Hebrew and Aramaic Lexicon of the Old Testament (Leiden: Brill 1994-1999) III.

Kraft, R. A., "Eis neikos = permanently/successfully: 1 Cor 15:54, Matt 12:20", Septuagintal Lexicography (ed. R. A. Kraft) (SCSt.SBL 1; [printed in Missouola, MT]: SBL 1972) 153-156.

Macintosh, A. A., A Critical and Exegetical Commentary on Hosea (ICC; Edinburgh: T \& T Clark 1997).

Morissette, R., "Un midrash sur la mort (I Cor., XV, 54c à 57)", Revue biblique 79 (1972) 161-188.

Moyise, S., "Does Paul Respect the Context of His Quotations? Hosea as Test Case", "What Does the Scripture say?" Studies in the Function of Scripture in Early Judaism and Christianity (ed. C. A. Evans - H. D. Zacharias) (LNTS 470; London - New York: T \& T Clark 2012) 39-50.

Muraoka, T., A Greek-English Lexicon of the Septuagint (Louvain - Paris - Dudley, MA: Peeters 2009).

Neusner, J., Hosea in Talmud and Midrash (Studies in Judaism; Lanham, MD - Toronto: Plymouth University Press of America 2007).

Ottley, R. R., The Book of Isaiah According to the Septuagint (Codex Alexandrinus), I, Text and Notes (Cambridge: Cambridge University Press 1906).

Payne Smith, R. et al., Thesaurus Syriacus (London: Oxford University Press, Clarendon Press 1879) I.

Schleusner, J. F., Novus Thesaurus philologico-criticus sive lexicon in LXX et reliquos interpretes graecos ac scriptores apocryphos Veteris Testamenti (Lipsiae: Verlag Weidmann 1820) II.

Tomson, P. J., “'Death, where is Thy Victory?' Paul's Theology in the Twinkling of an Eye”, Resurrection in the New Testament. Festschrift J. Lambrecht (ed. R. Bieringer - V. Koperski) (BETL 165; Leuven: Leuven University Press; Peeters 2002) 357-386.

van der Kooij, A., "Teacher Messiah and World-wide Peace. Some Comments on Symmachus' Version of Isaiah 25:7-8”, Journal of Northwest Semitic Languages 24 (1998) 75-82. 
Weitzman, M., "Recension of The Peshitta of the Twelve Prophets. By A. Gelston", Journal of Theological Studies 40 (1989) 162-165.

Wünsche, A., Der Prophet Hosea: Übersetzt und erklärt mit Benutzung der Targumim, der jüdischen Ausleger Raschi, Aben Ezra und David Kimchi (Leipzig: Weigel 1868). 
